\title{
HOW CONSUMER CONFIDENCE AFFECTS THE IMPACT OF HOUSING AND STOCK MARKET WEALTH ON CONSUMPTION? EVIDENCE FROM ASIAN COUNTRIES
}

\author{
(Bagaimana Kepercayaan Konsumen Memengaruhi Wealth Effect Pasar Perumahan dan \\ Pasar Saham terhadap Konsumsi? Bukti Empiris dari Negara-Negara Asia)
}

\author{
Heru Santoso* and Takeshi Inoue** \\ *Directorate of Special Housing, Directorate General of Housing Provision, \\ Indonesian Ministry of Public Works and Housing \\ Jl. Pattimura No. 20, Kebayoran Baru, South Jakarta, Email: heruwsanto@ymail.com \\ **Graduate School of International Cooperation Studies (GSICS), Kobe University \\ 2-1 Rokkodai-cho, Nada-ku, Kobe, Japan, Email: takeinoue@people.kobe-u.ac.jp
}

Naskah diterima: 15 November 2019

Naskah direvisi: 18 November 2019

Naskah diterbitkan: 31 Desember 2019

\begin{abstract}
Abstrak
Studi ini mengeksplorasi pengaruh kepercayaan konsumen terhadap wealth effect dari pasar perumahan dan pasar saham terhadap tingkat konsumsi di 10 negara Asia. Studi ini menggunakan data triwulanan dari kuartal pertama tahun 2010 hingga kuartal keempat tahun 2017 dan menggunakan metode panel Fully Modified Ordinary Least Square (FMOLS) untuk melihat hubungan jangka panjang antar variabel. Hasil studi menunjukkan bahwa kepercayaan konsumen berpengaruh terhadap wealth effect dari pasar perumahan dan pasar saham terhadap tingkat konsumsi. Secara rinci, interaksi dari kepercayaan konsumen dan wealth effect dari pasar perumahan memiliki dampak positif yang signifikan terhadap tingkat konsumsi, berbeda dengan wealth effect dari pasar perumahan yang sebelumnya tidak signifikan terhadap tingkat konsumsi. Di lain sisi, interaksi antara kepercayaan konsumen dan wealth effect dari pasar saham memiliki dampak negatif yang signifikan terhadap tingkat konsumsi, berbeda dengan wealth effect dari pasar saham yang sebelumnya positif dan signifikan terhadap tingkat konsumsi. Selain itu, hasil studi ini juga menunjukkan bahwa (1) negara-negara dengan perkembangan sektor keuangan yang lebih tinggi memiliki wealth effect dari pasar perumahan dan pasar saham yang lebih kuat dibandingkan negara-negara dengan perkembangan sektor keuangan yang lebih rendah dan (2) negaranegara dengan tingkat pendapatan yang lebih tinggi memiliki wealth effect dari pasar perumahan dan pasar saham yang lebih kuat dibandingkan negara-negara dengan tingkat pendapatan yang lebih rendah.

Kata kunci: kepercayaan konsumen, konsumsi, wealth effect pasar perumahan, wealth effect pasar saham, panel FMOLS
\end{abstract}

\begin{abstract}
This study explores the effect of consumer confidence in the impact of housing market and stock market wealth on private consumption for a panel of 10 Asian countries. This study using quarterly data from the $1^{\text {st }}$ quarter of 2010 to the $4^{\text {th }}$ quarter of 2017 and applies panel Fully Modified Ordinary Least Square (FMOLS) method to assess the long-term relationship between variables. The result shows that the inclusion of consumer confidence changes the previous impact of housing market wealth and stock market wealth on consumption. Particularly, the interaction between consumer confidence and housing market wealth has a positive and significant impact on consumption, which is different from the previous insignificant impact of housing market wealth on consumption. On the other hand, the interaction between consumer confidence and stock market wealth has a negative significant impact on consumption, which is different from the previous positive significant impact of stock market wealth on consumption. In addition, the supplementary findings of this study show (1) countries with higher financial sector development have stronger housing market and stock market wealth effect than countries with lower financial sector development and (2) countries with higher income level have stronger housing market and stock market wealth effect than countries with lower income level.
\end{abstract}

Keywords: consumer confidence, consumption, housing market wealth, stock market wealth, panel FMOLS

\section{INTRODUCTION}

It has been widely observed that the fluctuation of stock market and housing market could have a relation with the fluctuation of private consumption. In general, the increasing price of stock or houses creates the so-called "wealth effect" for stock owners and homeowners that leads to higher consumption spending (Case, et al., 2005).

From the stock market perspective, the increasing price of a stock or other financial assets gives additional wealth to the stock owners that can lead to higher consumption. Several studies have indicated the connection between fluctuation in stock market price and consumption in advanced economy such as U.S. General findings confirmed that the changes in stock market prices affected aggregate consumption spending growth (e.g. Lettau \& Ludvigson, 2001; Ludvigson \& Steindel, 1999; Poterba, 2000; Poterba \& Samwick, 1995; Starr \& McCluer, 2002). Poterba (2000) argued that a higher stock market price may increase consumption pressure, while a lower stock market price may contribute to economic 
activities slow down. The evidence was modest in Asian countries which have less developed financial sector than the U.S. For example, Funke (2004) investigated the effect of stock market wealth on private consumption in 16 emerging economies including Asia. He found evidence for a small and statistically significant impact of stock returns on private consumption growth. Singh (2012) studied the impact of stock market shocks on aggregate consumption in India and found that stock market wealth effect had a small impact on consumption. Moreover, Zhou, et al. (2016) found the unequal wealth effect of stock market on consumption in China. The response of consumption was positive and significant from a positive change of stock market price, while a negative change in stock market price had no significant effect on consumption.

From the housing market perspective, studies about the impact of housing market wealth on consumption have started to develop over the past years following the development of housing markets. many countries experience boom-busts in housing prices that may affect private or households' consumption. For example, Campbell \& Cocco (2007) and Attanasio, et al., (2009) found that, in the United Kingdom, increasing house prices raises homeowners' wealth and so their consumption. At the same time, higher housing price reduces homeowners' credit constraints because of the availability of collateral that could be obtained from their houses. In Asia, Gan (2010) studied the relationship between housing market wealth and consumption in Hong Kong and found a significant positive effect of housing market wealth on consumption, especially from the households that have multiple houses. In contrast, other studies didn't find a significant effect of increasing house prices on consumption (e.g. Cheng \& Fung, 2008; Cho, 2011; Wang-Li, et al., 2015). They supposed that a positive wealth effect of increasing house prices for homeowners was being counterweighted by a negative wealth effect for non-homeowners that came from the increasing cost of residential services.

Consumers may have different responses from the price fluctuations of their housing and financial assets (Benjamin, et al., 2004). On one side, some studies discovered that the fluctuation of stock market has a bigger impact on aggregate spending rather than the fluctuation of housing market. For example, Dvornak \& Kohler (2007) found that consumption is more sensitive to the change in stock prices than in house prices. They argued that stock is considered as a more liquid asset than a house. Liquidating a certain amount of stock is relatively less expensive than liquidating the same amount of house. Therefore, instead of refinancing their houses to increase their consumption spending, people tend to use their houses as a long-term asset or precautionary saving for the future. On the other side, Kishor (2007) found contradictory evidence that showed the increasing house prices could give a higher boost on consumption spending rather than an increasing stock price. They found that the Marginal Propensity to Consume (MPC) because of an increasing house price is relatively higher than the MPC because of an increasing stock price. They argued that shocks in housing market are more permanent than shocks in stock market. Because consumption mostly not respond to transitory shock, o the effect of the fluctuation in stock market on consumption is not as strong as the effect of the fluctuation in housing market.

In addition, another important factor that may affect consumers' spending is their expectationsabout the future. One variable that has been widely used as an indicator to measure consumers' perception of future economic conditions is consumer confidence. Consumer confidence represents consumers' psychological decision-making process in economic activity, particularly regarding their consumption (Çelik \& Özerkek, 2010). When people believe that the future economy will have a better condition, they may increase their consumption spending (Carroll, et al., 1998; Gelper, et al., 2007).

Some studies showed evidence of the impact of consumer confidence on consumption spending. For example, Ludvigson (2004) explored the relationship between movements in consumer confidence and movements in aggregate consumption growth in the U.S. He found mixed results regarding the impact of both consumer confidence indexes: modest on total consumption expenditure, strong on goods consumption (excluding motor vehicles), weak on services consumption, and negative (weakening the predictive power of the baseline model) on motor vehicles consumption. Gelper, et al. (2007) investigated whether consumer confidence affects future aggregate consumption spending in the U.S. They found that the current confidence index could predict future consumption by 4-5 months' time lag. Furthermore, they also discovered that the confidence index had more significant forecasting power when it was used to predict consumption in services compared with other components of consumption. In another region, Çelik \& Özerkek (2009) examined the relationship between consumer confidence, private consumption, and other economic and financial variables in 9 European Union countries during 1997-2006. They found a strong long-run relationship between personal 
consumption and consumer confidence with other economic and financial variables. In Asian countries, Fan \& Wong (1998) examined the predictive power of consumer confidence in consumption expenditure in Hong Kong and found that consumer confidence index has little and almost have no explanation ability on future consumption. Likewise, Kim \& Goo (2008) found that consumer confidence indexes have weak predictive power on future consumption in South Korea. Nevertheless, confidence indexes contain strong information about consumers' current consumption. In contrast, Can \& Yüncüler (2017) found that lagged value of consumer confidence, on its own, was significant in predicting future total, durable goods and non-durable goods consumption growth in Turkey. However, they found that the consumer confidence indexes had no significant predicting power in future consumption when other control variables were added to the model, meaning the indexes provided no unique information about future consumption growth.

Observing the role of consumer confidence in predicting consumption, it would be possible that the variable may affect the impact of stock market and housing market wealth in determining consumption. For instance, a better future economic condition gives different responses of stockholders and homeowners regarding the changes in their assets' price because of the different conditions of stock market and housing market. Fereidouni \& Tajaddini (2017) conducted a study and found that in the United States when people are optimistic about future economic conditions, the increasing house price will make homeowners spend more money on consumption. On the other hand, when people are optimistic about future economic conditions, the increasing stock price will reduce the stock owners' consumption. The finding implies that the increasing wealth because of the increasing stock market price is transitory. When stock owners feel optimistic about future economic and financial conditions, they will not spend their additional wealth on consumption immediately. Instead, they will spend more money in stock market in order to gain more returns in the future.

It is also important to investigate the findings of the study conducted by Fereidouni \& Tajaddini (2017) in other countries, such as Asia since many Asian countries are becoming financially developed in both stock and housing markets in recent years. Some studies have investigated the response of consumption due to the change of stock market price (e.g. Funke, 2004; Singh, 2012) and housing market price (Dong, et al., 2017; Gan, 2010) in Asian countries. Furthermore, the significance of consumer confidence surveys as a predictor of consumption in Asia started to draw researchers' attention (e.g. Fan \& Wong, 1998; Kim, 2016; Özerkek \& Çelik, 2010).

Regarding these issues, this study constructs the existing literature, by answering the research question from Fereidouni \& Tajaddini (2017): "how consumers' expectations about a future economic condition affect the impact of stock market and housing market wealth on consumption". Specifically, this study tries to observe the interaction between consumer confidence with both housing market wealth and stock market wealth as determinants of consumption.

In the empirical analysis, following Fereidouni \& Tajaddini (2017), this study estimates the models using panel Fully Modified Ordinary Least Square (FMOLS) to investigate the long-run relationship between variables. Based on their study, the reasons for using panel FMOLS method are because of the existence of endogeneity problem in the model. For example, this study assumes that the increasing price of stock and housing will raise consumption. However, a stronger economic activity like increasing aggregate consumption could lead to higher stock and housing prices (Fereidouni \& Tajaddini, 2017; Gholipour, 2013; Poterba \& Samwick, 1995). In addition, to deepen the analysis, besides using the whole sample, this study will separate the sample countries based on two classifications: level of financial sector development and income level. Firstly, the level of financial sector development could be a key aspect of stock market capitalization and the liquidity process of housing equity in a country. lacoviello (2011) considered the level of financial development and liquidity in a country as an important determinant of consumption. Secondly, the income level is an important factor that affects assets ownership in a country. Cho (2011) suggested that homeownership could make the wealth effect of housing market on consumption is getting stronger, as Poterba (2000) showed the importance of households' level of stock ownership in the impact of stock market wealth on consumption.

This study contributes to the current empirical literature about the determinant of consumption, which is mostly the biggest portion of Gross Domestic Product (GDP) in many countries. First, this study will consider a variable that rarely used, consumer confidence, as an indicator to measure consumers' expectations of future economic conditions in stock market and housing market. Second, this study will present the evidence of the issue from the study conducted by Fereidouni \& Tajaddini (2017) in emerging Asian countries, and surprisingly, there is limited literature relating to this issue. Finally, from 
the findings, this study will present policy implications about whether stock market or housing market has a primary role in economic and financial stabilization.

This study is organized as follows: the next part describes the empirical methodology and data specification used in the study, followed by the empirical results and discussion. Finally, the final part concludes the results and discussion with policy implications.

\section{METHOD}

The aim of this study is to examine whether consumer confidence affects the impact of stock market and housing market wealth on consumption expenditure. Based on a study conducted by Fereidouni \& Tajaddini (2017), the base model for this study is specified as below:

$$
\begin{aligned}
\operatorname{lnc} c_{t}= & \alpha_{0}+\alpha_{1} \operatorname{lng} y_{t}+\alpha_{2} \operatorname{lnhpi} i_{t}+\alpha_{3} \operatorname{lnspi} i_{t}+\alpha_{4} c c i_{t}+ \\
& \gamma_{1}\left[\operatorname{lnhpi} i_{t}{ }^{*} c c i_{t}\right]+\gamma_{2}\left[\operatorname{lnspi} i_{t}^{*} c c i_{t}\right]+\varepsilon_{t} \ldots . .(1)
\end{aligned}
$$

Where $c_{t}$ is total consumption expenditure, $y_{t}$ is GDP per capita, $h p i_{t}$ is housing market wealth (proxied by house price index), spi is stock market wealth (proxied by stock market index), $c c i_{t}$ is consumer confidence index, [hpi ${ }^{*} c \mathrm{ci} \mathrm{i}_{\mathrm{t}}$ is an interaction between housing market wealth and consumer confidence, $\left[\mathrm{spi}_{t}{ }^{*} \mathrm{cci} \mathrm{i}_{t}\right]$ is an interaction between stock market wealth and consumer confidence.

Following Fereidouni \& Tajaddini (2017), this study will estimate the model with FMOLS method with panel data. FMOLS for heterogeneous cointegrated panel was established by Pedroni (2000) to assess the long-run relationship between variables. Moreover, to deepen the analysis, the additional results of this study will split the sample based on two categories: level of financial sector development (proxied by the ratio of stock market capitalization to GDP) and income level (proxied by GDP per capita). The purpose to split the sample based on financial sector development is to confirm that the level of financial sector development may contribute to the different magnitude of housing market and stock market wealth effect on consumption for countries with higher financial sector development and countries with lower financial sector development. Likewise, by splitting the sample countries based on income level, this study also wants to confirm that the income level of a country could distinct the magnitude of housing market and stock market wealth effect for countries with higher income level and countries with lower income level. These two classifications are measured from the World Bank data at the end of 2017.

The data set of this study consists of 10 Asian countries (China, Hong Kong, India, Indonesia, South
Korea, Malaysia, Philippines, Taiwan, Thailand, and Turkey). The period covered is from $20101^{\text {st }}$ quarter to $20174^{\text {th }}$ quarter. Data of total private consumption expenditure and GDP per capita are obtained from the IMF's International Financial Statistics for all sample countries except Taiwan, which is collected from National Statistics of Taiwan. Data of housing market wealth and stock market wealth are proxied by house price index and stock market index. Data of house price index are obtained from the Bank of International Settlements (BIS) combined with Euromonitor database. For stock market index, the data are obtained from Euromonitor database. Data of consumer confidence indexes are obtained from Euromonitor database for all countries except for India. Data of India Consumer Confidence Index are obtained from the Reserve Bank of India. All consumption and GDP per capita data are in nominal domestic currencies. To get the real values and remove the effect of inflation, the nominal data are deflated by Consumer Price Index (CPI) of each country, then converted into U.S. dollar (USD) by using real exchange rate (local currency/USD) and deflated by population to get the per capita terms. Data of house price index and stock market index are in nominal terms and have the same 2010 base year. The nominal indexes then deflated by the CPI of each country to get the real terms. Data of consumer confidence indexes use a standardized calculation methodology for cross-country comparison. The standard deviations of each observation are above and below the long-term mean. The farther the index from zero with positive numbers, the more optimistic households are about future economic conditions. The far the index from zero with negative numbers, the more pessimistic households towards future economic conditions.

Finally, to interpret the estimation results as the elasticities of consumption from the changes of all regressors, a natural logarithm has been taken for all variables, except for consumer confidence index. The reason why the consumer confidence index is not in natural logarithm form is the data of consumer confidence index for the Philippines have a negative value for some period, meaning consumers are extremely pessimistic.

\section{RESULTS AND DISCUSSION}

Unit root test is the first stage in time series analysis to verify the stationarity of the variables. This study employs panel unit root test developed by Im-Pesaran-Shin (IPS). The null hypothesis of the IPS test is that all variables contain a unit root or nonstationary. The results are shown in Table 1 . In general, the stationary property of all variables in levels shows 
Table 1. Im-Pesaran-Shin Panel Unit Root Test

\begin{tabular}{|c|c|c|c|c|c|}
\hline Variable & Specification & t-statistic & Variable & Specification & t-statistic \\
\hline \multirow{2}{*}{ Incons } & Constant \& Trend & 0.3706 & \multirow{2}{*}{$\Delta$ Incons } & Constant \& Trend & $-3.4803 * * *$ \\
\hline & Constant & $-1.6533^{*}$ & & Constant & $-2.3719 * * *$ \\
\hline \multirow{2}{*}{$\ln g d p$} & Constant \& Trend & -0.6268 & \multirow{2}{*}{$\Delta \ln g d p$} & Constant \& Trend & $-7.8096 * * *$ \\
\hline & Constant & $-2.4403 * *$ & & Constant & $-8.5184^{* * *}$ \\
\hline \multirow{2}{*}{ Inhpi } & Constant \& Trend & 1.3866 & \multirow{2}{*}{$\Delta \operatorname{lnhpi}$} & Constant \& Trend & $-6.2064 * * *$ \\
\hline & Constant & 0.8482 & & Constant & $-8.9397^{* * *}$ \\
\hline \multirow{2}{*}{ Inspi } & Constant \& Trend & -0.7062 & \multirow{2}{*}{$\Delta \operatorname{lnspi}$} & Constant \& Trend & $-9.7959 * * *$ \\
\hline & Constant & -0.8221 & & Constant & $-10.1733^{* * *}$ \\
\hline \multirow{2}{*}{$c c i$} & Constant \& Trend & -0.9972 & \multirow{2}{*}{$\Delta c c i$} & Constant \& Trend & $-7.9594 * * *$ \\
\hline & Constant & -0.8900 & & Constant & $-9.3434 * * *$ \\
\hline \multirow{2}{*}{$(\operatorname{lnhpi*cci)}$} & Constant \& Trend & -0.3380 & \multirow{2}{*}{$\Delta(\operatorname{lnhpi*} c c i)$} & Constant \& Trend & $-8.9734^{* * *}$ \\
\hline & Constant & 0.4550 & & Constant & $-9.3441 * * *$ \\
\hline \multirow{2}{*}{$\left(\operatorname{lnspi*}{ }^{*} c c i\right)$} & Constant \& Trend & -0.8478 & \multirow{2}{*}{$\Delta(\operatorname{Inspi*} c c i)$} & Constant \& Trend & $-8.2615^{* * *}$ \\
\hline & Constant & -0.2348 & & Constant & $-11.0427^{* * *}$ \\
\hline
\end{tabular}

Note: $\quad * * *$ denotes significance at 1 percent level.

** denotes significance at 5 percent level.

* denotes significance at 10 percent level.

Source: author (2019).

the small values do not exceed the absolute terms of critical values. After the first difference was taken for each variable, the large negative values show that the null hypothesis is rejected at 1 percent level. Therefore, all series of variables are non-stationary and integrated in order one I(1).

Given all variables are I(1), the next stage is to test the presence of a long-run relationship between variables using co-integration test. This study uses Fisher's (combined Johansen) panel co-integration test. The test uses both Johansen's Trace and MaxEigen statistics (Johansen, 1988). The null hypothesis

Table 2. Fisher (Combined Johansen) Panel Cointegration Test

\begin{tabular}{lccc}
\hline \multirow{1}{*}{ Test } & $\begin{array}{c}\text { Null } \\
\text { Hypothesis }\end{array}$ & $\begin{array}{c}\text { Test } \\
\text { statistics }\end{array}$ & p-value \\
\hline \multirow{3}{*}{ Trace test } & $\mathrm{R}=0$ & 363.600 & 0.000 \\
\cline { 2 - 4 } & $\mathrm{R}=1$ & 222.200 & 0.000 \\
\cline { 2 - 4 } & $\mathrm{R}=2$ & 118.200 & 0.000 \\
\cline { 2 - 4 } & $\mathrm{R}=3$ & 74.280 & 0.000 \\
\hline & $\mathrm{R}=4$ & 44.780 & 0.001 \\
\cline { 2 - 4 } & $\mathrm{R}=0$ & 189.500 & 0.000 \\
\cline { 2 - 4 } Max-Eigenvalue test & $\mathrm{R}=1$ & 121.700 & 0.000 \\
\cline { 2 - 4 } & $\mathrm{R}=2$ & 54.500 & 0.000 \\
\cline { 2 - 4 } & $\mathrm{R}=3$ & 43.650 & 0.002 \\
\cline { 2 - 4 } & $\mathrm{R}=4$ & 30.430 & 0.063 \\
\hline
\end{tabular}

Note: $\mathrm{R}$ indicates the number of cointegrating vectors under the null hypothesis.

Source: author (2019). is there is no co-integration between variables. As the results show in Table 2, both Trace and MaxEigen statistics reject the null hypothesis at 1 percent significance level. Thus, there is a co-integration relationship between variables.

Given the presence of co-integration, the next step is to estimate the long-run relationship between

Table 3. Panel FMOLS Result Dependent variable: Incons

\begin{tabular}{lc}
\hline \multirow{2}{*}{ Ingdp } & $0.8500^{* * *}$ \\
\cline { 2 - 2 } Inhpi & $(0.0833)$ \\
\hline \multirow{2}{*}{ Inspi } & 0.0250 \\
\hline \multirow{2}{*}{ cci } & $(0.2256)$ \\
\cline { 2 - 2 } & $0.1861^{* *}$ \\
\hline \multirow{2}{*}{ Inhpi*cci } & $(0.0774)$ \\
\hline \multirow{2}{*}{ Inspi* ${ }^{*} c c i$} & -0.0087 \\
\hline Obs & $(0.0125)$ \\
\hline $\mathrm{R}^{2}$ & $0.0041^{*}$ \\
\hline Adj $\mathrm{R}^{2}$ & $(0.0023)$ \\
\hline
\end{tabular}

Note: Figures in parentheses are robust standard errors.

$* * *$ denotes significance at 1 percent level.

** denotes significance at 5 percent level.

* denotes significance at 10 percent level. Source: author (2019). 
variables using panel FMOLS method developed by Pedroni (2000). Table 3 presents the results of panel FMOLS estimation.

The results show that GDP per capita has an expected positive and statistically significant impact on consumption expenditure per capita. The coefficient of Inhpi shows that the impact of the variable on Incons is positive but not significant. The result is in contrast with previous studies that found positive significant effect of housing market wealth on consumption (e.g. Attanasio, et al., 2009; Benjamin, et al., 2004; Bostic, et al., 2009; Campbell \& Cocco, 2007; Carroll, et al., 2011; Case, et al., 2005; Kishor, 2007). However, this finding is in line with other previous studies that found insignificant, at some point negative, housing market wealth effect on consumption (e.g. Browning, et al., 2013; Levin, 1998; Paiella, 2007). Particularly, the finding is also consistent with the previous evidence from Asian countries (Chen, et al., 2009; Cho, 2011; Lin \& Lai, 2003; Wang-Li, et al., 2015). Theoretically, the MPC of less liquid assets is relatively smaller than the MPC of more liquid assets (Cheng \& Fung, 2008; Levin, 1998). Housing is considered as a less liquid asset, and households require more cost and a longer period to refinance a house into cash. Thus, households cannot immediately possess additional money from their appreciated house value (Wang-Li, et al., 2015). Instead, they using their higher housing value for a long-term asset or precautionary saving (Dvornak \& Kohler, 2007). Moreover, a positive wealth effect of the increasing house price is only limited to homeowners who intend to refinance their assets and use it for consumption, while there is no effect on those who do not intend to refinance and prefer to keep their assets. In addition, an increasing house price can cause a negative price effect to nonhomeowners and, at a certain point, could offset the positive wealth effect, creating a crowding-out effect. A future home buyer may have to reduce their spending on other consumption to save more money for home purchasing purposes (Zhou, et al., 2016).

On the other hand, the positive significant coefficient of Inspi shows a positive impact of stock market wealth on consumption. A 10 percent increase in stock market price raises per capita consumption expenditure by 1.86 percent. The finding is in line with the literature that found positive and statistically significant stock market wealth effect on consumption (e.g. Funke, 2004; Lettau \& Ludvigson, 2001; Ludvigson \& Steindel, 1999; Poterba, 2000; Poterba \& Samwick, 1995; Singh, 2012; Starr \& McCluer, 2002; Zhou, et al., 2016). The increasing price of a stock and other financial assets will generate higher stockholders' wealth and so higher consumption. In addition, the increasing stock market prices signal that the financial sector of a country is growing positively, and that leads to a better general economic condition. Thus, even though there are consumers who do not own stock, a better economic condition increases the confidence of all households to spend more money on goods and services consumption (Poterba, 2000). Furthermore, stock and other financial assets are considered as more liquid assets. Stockholders do not require high costs and long-time period to cash out their financial assets (Dvornak \& Kohler, 2007). As a result, they could use the additional cash of appreciated assets to finance their consumption immediately.

Regarding the impact of the consumer confidence index, the result shows that cci, on its own, is not significant in affecting per capita consumption expenditure. This result is consistent with previous studies that showed small or no effect of consumer confidence on consumption (e.g. Croushore, 2005; Fan \& Wong, 1998; Howrey, 2001; Kim \& Goo, 2008). Nevertheless, when the index interacts with both house prices and stock price, it changes the previous impacts of housing market wealth and stock market wealth on consumption. For instance, the interaction between consumer confidence index with housing price index (Inhpi*cci) has a positive and significant impact on consumption. The increasing house price may have an insignificant impact on households' current consumption, but the presence of additional information about future economic conditions may contribute to households' perception of their consumption spending. The homeowners will increase their consumption because of the higher value of their assets that could be used as collateral, and at the same time, they feel confident about future economic conditions, including their future incomes (Fereidouni \& Tajaddini, 2017). For the non-homeowners or those wanting to buy a house, information about better future economic conditions reduces the uncertainty that may deter them from consuming more. Even though the house they intend to buy has an increased price, when they feel secure about their future incomes to close the down payment and other costs associated with house purchasing, they still can raise their current consumption.

On the other hand, the interaction between consumer confidence index and stock market index (Inspi*cci) shows a negative and significant impact on consumption per capita. The finding is consistent with the study conducted by Fereidouni \& Tajaddini (2017). The reason is that the stock market is more vulnerable from short-term macroeconomic shocks, and that makes wealth that can be obtained from 
stock market is more transitory. Thus, when stock price increases, the optimistic stockholders may not immediately refinance their financial assets and use it to raise their consumption. Instead, they may spend their resources more in financial markets to get future higher returns from their investments. However, this condition can be fulfilled only if the country has a well-developed financial sector. To support the findings, this study will differentiate the sample countries based on the financial sector development and income level of each country.

Based on financial sector development, the sample countries are simply divided into two subsamples: higher financial sector development and lower financial sector development. Financial sector development is proxied by the ratio of stock market capitalization to GDP, measured based on the World Bank data at the end of 2017. The ratio of stock market capitalization to GDP is widely used as an approximation of the level of financial sector development (e.g. Caporale \& Sousa, 2016; Peltonen, et al., 2012). The group of countries which is classified as higher financial sector development are Hong Kong, Taiwan, Malaysia, Thailand, and South Korea; while the group of lower financial sector development is Philippines, India, China, Indonesia, and Turkey ${ }^{1}$.

The results in Table 4 suggest that GDP per capita is positive and statistically significant in affecting consumption per capita for both subsamples. Regarding the impact of housing market wealth, Inhpi is positive for higher financial sector development countries and negative for lower financial sector development countries, and both show insignificant coefficients. The more developed financial sector leads to a more advanced financial system that reduces market frictions and transaction costs, including housing refinancing costs. Moreover, a more developed financial sector provides various financial products and lending channels that offers more access to homeowners to refinance their assets (Dong, et al., 2017). If access to house refinancing is limited, it contributes to an insignificant housing market wealth effect (Zhou, et al., 2016). On the other hand, Inspi is positive and statistically significant for both sub-sample countries, with a higher magnitude for higher financial sector development countries (0.2106) than for lower financial sector development countries (0.0685). This finding emphasizes a stronger stock market wealth in high financial sector development countries.

1 The division of sub-sample groups is simply by splitting the sample countries into 2 groups: countries with higher ratio of stock market capitalization to GDP and countries with lower ratio of stock market capitalization to GDP.
The result also shows that cci does not have a significant impact on consumers directly, but only through its interaction with Inhpi and Inspi. The inclusion of cci makes the previous insignificant impact of Inhpi become positive and statistically significant, with a relatively higher magnitude for higher financial sector development countries (0.0207) than for lower financial sector development countries (0.0036). On the other hand, cci makes the previous positive significant impact of Inspi become negative and significant, with higher sensitivity of consumption for higher financial sector development countries $(-0.0028)$ than for lower financial sector development countries (-0.0009). The evidence supports the main finding that showed the wealth gains from housing and financial assets that could be extracted by homeowners and stockholders is higher in countries with higher financial sector development. Furthermore, as Aron, et al. (2012) found in their study, in the countries where consumers have limited access to consumer and mortgage credit, the increasing house price leads to higher savings for a house down payment cost purposes and creates a negative wealth effect.

Another way to split the sample countries is based on the income level of the country (proxied by GDP per capita), measured from the World Bank data at the end of 2017. The group of countries

Table 4. Panel FMOLS Financial Sector Development Dependent Variable: Incons

\begin{tabular}{|c|c|c|c|}
\hline \multicolumn{2}{|c|}{ Variable } & $\begin{array}{c}\text { Higher Financial } \\
\text { Development }\end{array}$ & $\begin{array}{c}\text { Lower Financial } \\
\text { Development }\end{array}$ \\
\hline \multirow{2}{*}{\multicolumn{2}{|c|}{$\ln g d p$}} & $0.4353 * * *$ & $0.3624^{* * *}$ \\
\hline & & $(0.0284)$ & $(0.0560)$ \\
\hline \multirow{2}{*}{\multicolumn{2}{|c|}{ Inhpi }} & 0.0826 & -0.1806 \\
\hline & & $(0.0670)$ & $(0.1436)$ \\
\hline \multirow{2}{*}{\multicolumn{2}{|c|}{ Inspi }} & $0.2106 * * *$ & $0.0685^{*}$ \\
\hline & & $(0.0343)$ & $(0.0392)$ \\
\hline \multirow{2}{*}{\multicolumn{2}{|c|}{ cci }} & 0.0095 & -0.0115 \\
\hline & & (0.0039) & $(0.0075)$ \\
\hline \multirow{2}{*}{\multicolumn{2}{|c|}{ Inhpi*cci }} & $0.0207^{*}$ & $0.0036 * *$ \\
\hline & & 0.0008 & $(0.0014)$ \\
\hline \multirow{2}{*}{\multicolumn{2}{|c|}{ Inspi*cci }} & $-0.0028 * * *$ & $-0.0009 * *$ \\
\hline & & $(0.0004)$ & $(0.0004)$ \\
\hline \multicolumn{2}{|l|}{ Obs } & 160 & 160 \\
\hline \multicolumn{2}{|l|}{$\mathrm{R}^{2}$} & 0.9983 & 0.9944 \\
\hline \multicolumn{2}{|l|}{ Adj $R^{2}$} & 0.9981 & 0.9938 \\
\hline Note: & \multicolumn{3}{|c|}{$\begin{array}{l}\text { Figures in parentheses are robust standard errors. } \\
* * * \text { denotes significance at } 1 \text { percent level. } \\
* * \text { denotes significance at } 5 \text { percent level. } \\
* \quad \text { denotes significance at } 10 \text { percent level. }\end{array}$} \\
\hline \multicolumn{4}{|c|}{ Source: author (2019). } \\
\hline
\end{tabular}


which is classified as higher income level are Hong Kong, South Korea, Taiwan, Turkey, and Malaysia; while the group of the lower-income level is China, Thailand, Philippines, Indonesia, and India².

From the results in Table 5, it can be seen that, as the income level of a country is getting higher, the wealth effect from stock market is getting stronger. The magnitude of Inspi for higher income level countries (0.1544) is higher than for lowerincome level countries (0.0368). This implies that the possibility of owning stock and other financial assets is relatively higher in countries with higher income level, so the wealth effect of increasing assets price is relatively stronger. However, the coefficients of Inhpi are not significant, which means the impact of housing market wealth on consumption is not significant for both sub-sample countries.

Regarding the impact of consumer confidence, the evidence shows similar results from all sample countries and financial sector development. cci only affects Incons by interacting with both Inhpi and Inspi. In particular, the interaction between cci and Inhpi has a positive and significant effect on consumption for both sub-samples countries, but the magnitude in countries with higher income level is stronger $(0.0055)$ than for countries with lower income level (0.0004). The higher the income level of a country, the

Table 5. Panel FMOLS Income Level Dependent Variable: Incons

\begin{tabular}{|c|c|c|c|}
\hline \multicolumn{2}{|c|}{ Variable } & Higher Income Level & Lower Income Level \\
\hline \multirow{2}{*}{\multicolumn{2}{|c|}{$\ln g d p$}} & $0.3672 * * *$ & $0.2679 * * *$ \\
\hline & & $(0.0390)$ & $(0.0675)$ \\
\hline \multirow{2}{*}{\multicolumn{2}{|c|}{ Inhpi }} & -0.4045 & -0.2627 \\
\hline & & $(0.1822)$ & $(0.1251)$ \\
\hline \multirow{2}{*}{\multicolumn{2}{|c|}{ Inspi }} & $0.1544^{*}$ & $0.0158 * * *$ \\
\hline & & $(0.1713)$ & $(0.0368)$ \\
\hline \multirow{2}{*}{\multicolumn{2}{|c|}{ cci }} & -0.0144 & -0.0084 \\
\hline & & $(0.0122)$ & $(0.0070)$ \\
\hline \multirow{2}{*}{\multicolumn{2}{|c|}{$\operatorname{lnhpi*cci}$}} & $0.0055^{* *}$ & $0.0004^{* * *}$ \\
\hline & & $(0.0021)$ & $(0.0013)$ \\
\hline \multirow{2}{*}{\multicolumn{2}{|c|}{ Inspi*cci }} & $-0.0027^{*}$ & $-0.0013 * * *$ \\
\hline & & $(0.0021)$ & $(0.0004)$ \\
\hline \multicolumn{2}{|l|}{ Obs } & 160 & 160 \\
\hline \multicolumn{2}{|l|}{$R^{2}$} & 0.9945 & 0.9878 \\
\hline \multicolumn{2}{|l|}{ Adj $R^{2}$} & 0.9942 & 0.9865 \\
\hline Note: & \multicolumn{3}{|c|}{$\begin{array}{l}\text { Figures in parentheses are robust standard errors. } \\
* * * \text { denotes significance at } 1 \text { percent level. } \\
* * \text { denotes significance at } 5 \text { percent level. } \\
* \quad \text { denotes significance at } 10 \text { percent level. }\end{array}$} \\
\hline
\end{tabular}

2 Like financial sector development, sample countries are simply divided into two sub-samples: countries with higher GDP per capita and countries with lower GDP per capita. higher the possibility of homeownership. Thus, the optimistic homeowners can raise their consumption when their house value is increased. On the other hand, the interaction between cci and Inspi has a negative significant effect on consumption, with higher sensitivity of consumption for countries with higher income level (-0.0027) than for countries with lower income level (-0.0013). However, the limited size of the sample may influence the estimation results for all model specifications.

\section{CONCLUSION}

This study investigates the role of consumer confidence (cci) in the impact of housing market wealth (hpi) and stock market wealth (spi) on consumption in Asia. This study using quarterly data from 10 Asian countries China, Hong Kong, India, Indonesia, South Korea, Malaysia, Philippines, Taiwan, Thailand, and Turkey, from $20101^{\text {st }}$ quarter to $20174^{\text {th }}$ quarter. Using panel FMOLS method, the main finding of this study is that consumer confidence changes the previous impact of housing market wealth and stock market wealth on consumption. Specifically, the interaction between cci and hpi has a positive and significant effect on consumption expenditure, which is different from the previous inconclusive and insignificant impact of hpi on consumption. Consumer confidence gives consumers additional information about future general economic conditions. The homeowners will have higher perceived wealth from the increasing value of their assets, and at the same time, they are optimistic about their future incomes. As a result, they could increase their consumption. For the non-homeowners or potential home buyers, the higher confidence level reduces the uncertainty about future economic conditions, including their future incomes. Therefore, even though house price is increased, homebuyers can close the homepurchasing costs by using the expected higher future earnings while they still increase their consumption.

On the other hand, the interaction between cci and spi shows a negative significant impact on consumption, which is different from the previous positive significant effect of spi on consumption. This finding is probably because the stock market is more vulnerable from short-term macroeconomic shocks, and so the wealth gained from stock market is transitory. Thus, when the stock price is increased, the optimistic stockholders may not immediately refinance their financial assets and use it to raise their consumption. Instead, they may spend their resources more in financial markets to get future higher returns from their investments. This condition requires a well-developed financial market. However, the results show an insignificant direct impact of 
consumer confidence on consumption. Therefore, consumer confidence does not affect consumption directly, but only has an impact by interacting with housing market wealth and stock market wealth.

In addition, the supplementary findings support the main result by categorizing the sample countries based on the level of financial sector development and income level. The additional results suggest that (1) the more developed the financial sector, the higher wealth and capital gains from housing and stock that could be withdrawn by homeowners and stockholders, (2) countries with higher income level have a relatively higher asset ownership possibility, so that the wealth effect of increasing price of assets will be stronger.

This study contributes to the current empirical literature (1) it investigates how consumer confidence affects the impact of housing market and stock market wealth on consumption in Asian countries, (2) it explores the country characteristics to support the main findings by splitting the sample countries based on financial sector development and income level, and (3) it extends the existing literature by using updated data.

This study found important evidence that provides implications for policymakers. Regarding the insignificant impact of housing market on consumption in sample countries, this is possible because of two reasons. Firstly, Asian countries have less developed financial sectors than advanced countries like U.S. A well-developed financial sector provides better financial services such as low-cost deductible refinancing, home equity loans and various mortgage financing products and channels. With the availability of various financial services, homeowners can liquidate their assets with low cost and simple procedures to finance their consumption, and that leads to higher economic growth. So, policymakers need to facilitate financial sector development and promoting financial products. Secondly, the low rate of homeownership may affect the insignificant wealth effect of housing market on consumption. The increasing house price can create a negative price effect for the non-homeowners and, at a certain point, could offset the positive wealth effect for the homeowners. Even though the homeownership of Asian countries is not at the lowest rate, the recent housing bubbles could discourage potential homebuyers in the future. First of all, policymakers should make suitable housing market policies to ensure stability in housing market development. In particular, the housing price should be maintained at a reasonable and affordable level. If so, that will increase the homeownership, and as a result, more consumers can refinance their house to finance higher consumption. This will, in turn, boost economic growth. Then, policymakers should increase housing supply, including public housing. Public housing plays a pro-cyclical role in private consumption growth (Edelstein \& Lum, 2004). The wealth effect of the public housing sector is more permanent than private housing. Public housing is allocated at subsidized rates which makes it more affordable for a wider range of consumers.

In the meantime, because the fluctuation in stock market could affect stockholders' consumption directly and non-stockholders' consumption indirectly, it could be a representation of the whole economic and financial conditions in a country (Poterba, 2000). However, it is widely known that stock market price is vulnerable from macroeconomic shocks with high volatility. Thus, policymakers need to assist stable stock markets by organizing suitable monetary policies to prevent considerable negative effects on the economy. Moreover, if policymakers strengthen the development of the financial market, it could lead to more predictable stock market returns and stock market wealth. Therefore, a well-developed financial market contributes to a good business environment that can attract private investment and, eventually, enhance the long-term economic growth (Caporale \& Sousa, 2016).

Regarding the role of consumer confidence in the effect of housing market and stock market wealth on consumption, consumers' expectation about future economic condition is an important issue to be handled. Maintaining consumers' perception of good economic conditions should be a fundamental goal for governments in the future.

\section{REFERENCES}

\section{Book}

Pedroni, P. (2000). Fully modified OLS for heterogeneous cointegrated panels. In Badi H.B., Thomas B.F., \& R. Carter H. (Eds.). Nonstationary panels, panel cointegration, and dynamic panels (Advances in econometrics, Vol. 15 (93-130). Bingley: Emerald Group Publishing Limited.

\section{Journal}

Aron, J., Duca, J.V., Muellbauer, J., Murata, K., \& Murphy, A. (2012). Credit, housing collateral, and consumption: Evidence from Japan, the U.K., and the U.S. Review of Income and Wealth, 58(3), 397-423. 
Attanasio, O.P., Blow, L., Hamilton, R., Leicester, A., (2009). Booms and busts: Consumption, house prices, and expectations. Economica, 76(301), 20-50.

Benjamin, J.D., Chinloy, P., \& Jud, G.D. (2004). Real estate versus financial wealth in consumption. Journal of Real Estate Finance and Economics, 29(3), 341-354.

Bostic, R., Gabriel, S., \& Painter, G. (2009). Housing wealth, financial wealth, and consumption: New evidence from microdata. Regional Science and Urban Economics, 39(1), 79-89.

Browning, M., Gørtz, M., \& Leth-Petersen, S. (2013). Housing wealth and consumption: A micro panel study. The Economic Journal, 123(568), 401-428.

Campbell, J.Y., \& Cocco, J.F. (2006). How do house prices affect consumption? Evidence from microdata. Journal of Monetary Economics, 54(2007), 591-621.

Can, H.G.K., \& Yüncüler, Ç. (2017). The explanatory power and the forecast performance of consumer confidence indices for private consumption growth in Turkey. Emerging Markets Finance and Trade, 54(9), 1-17.

Caporale, M.G., \& Sousa, R.M. (2016). Consumption, wealth, stock and housing returns: Evidence from emerging markets. Research in International Business and Finance, 36(1), 562-578.

Carroll, C.D., Fuhrer, J.C., \& Wilcox, D.W. (1994). Does consumer sentiment forecast household spending? If so, why? The American Economic Review, 84(5), 1397-1408.

Carroll, C.D., Otsuka, M., \& Slacalek, J. (2011). How large are housing and financial wealth effects? A new approach. Journal of Money, Credit and Banking, 43(1), 55-79.

Case, K.E., Quigley, J.M., \& Shiller, R.J. (2005). Comparing wealth effects: The stock market versus the housing market. Advances in Macroeconomics, 5(1), 1-32.

Çelik, S., \& Özerkek, Y. (2009). Panel cointegration analysis of consumer confidence and personal consumption in the European Union. Journal of Business Economics and Management, 10(2), 161-168.

Chen, J., Guo, F., \& Zhu, A. (2009). Housing wealth, financial wealth and consumption in China. China and World Economy, 17(3), 57-74.
Cheng, A.C.S., \& Fung, M.K. (2008). Financial market and housing wealth effects on consumption: A permanent income approach. Applied Economics, 40(23), 3029-3038.

Cho, S. (2011). Housing wealth effect on consumption: Evidence from household-level data. Economics Letters, 113(2), 192-194.

Croushore, D. (2005). Do consumer-confidence indexes help forecast consumer spending in real-time? North American Journal of Economics and Finance, 16(3), 435-450.

Dees, S., \& Brinca, P.S. (2013). Consumer confidence as a predictor of consumption spending: Evidence for the United States and the Euro area. International Economics, 134(1), 1-14.

Dong, Z., Hui, E.C. M., \& Jia, S.H. (2017). How does housing price affect consumption in China: Wealth effect or substitution effect? Cities, 64(1), 1-8.

Dvornak, N., \& Kohler, M. (2007). Housing wealth, stock market wealth and consumption: A panel analysis for Australia. The Economic Record, 83(261), 117-130.

Edelstein, R.H., \& Lum, S.K. (2004). House prices, wealth effects, and the Singapore macroeconomy. Journal of Housing Economics, 13(4), 342-367.

Fan, C.S., \& Wong, P. (1998). Does consumer sentiment forecast household spending? The Hong Kong case. Economics Letters, 58(1), 77-84.

Fereidouni, H.G., \& Tajaddini, R. (2017). Housing wealth, financial wealth and consumption expenditure: The role of consumer confidence. Journal of Real Estate Finance and Economics, 54(2), 216-236.

Funke, N. (2004). Is there a stock market wealth effect in emerging markets? Economics Letters, 83(3), 417-421.

Gan, J. (2010). Housing wealth and consumption growth: Evidence from a large panel of households. Review of Financial Studies, 23(6), 2229-2267.

Gelper, S., Lemmens, A., \& Croux, C. (2007). Consumer sentiment and consumer spending: Decomposing the Granger Causal relationship in the time domain. Applied Economics, 39(1), 1-11. 
Howrey, E.P. (2001). The predictive power of the index of consumer sentiment. Brooking Papers on Economic Activity, 1, 175-216.

Im, K.S., Pesaran, M.H., \& Shin, Y. (2003). Testing for unit roots in heterogeneous panels. Journal of Econometrics, 115(1), 53-74.

Johansen, S. (1988). Statistical analysis of cointegration vectors. Journal of Economic Dynamics and Control, 12(2-3), 231-254.

Kim, J. (2016). Consumer confidence and economic activity: What causes what? Korea and the World Economy, 17(2), 183-212.

Kim, Y., \& Goo, S. (2008). Is the consumer sentiment index useful in predicting household consumption ? A directional analysis with Korean data. The Journal of the Korean Economy, 9(2), 205-235.

Kishor, N.K. (2007). Does consumption respond more to housing wealth than to financial market wealth? If so, why? Journal of Real Estate Finance and Economics, 35(4), 427-448.

Lettau, M., \& Ludvigson, S. (2001). Consumption, aggregate wealth, and expected stock returns. The Journal of Finance, 56(3), 815-849.

Levin, A., Lin, C.-F., \& Chu, C.-S. J. (2002). Unit root test in panel data: Asymptotic and finite-sample properties. Journal of Econometrics, 108, 1-24.

Levin, L. (1998). Are assets fungible? Testing the behavioral theory of life-cycle savings. Journal of Economic Behavior and Organization, 36, 59-83.

Lin, C.-C., \& Lai, Y.-F. (2003). Housing prices, mortgage payments and savings behavior in Taiwan: A time series analysis. Asian Economic Journal, 17(4), 407-425.

Ludvigson, S.C. (2004). Consumer confidence and consumer spending. The Journal of Economic Perspectives, 18(2), 29-50.

Ludvigson, S., \& Steindel, C. (1999). How important is the stock market's effect on consumption? Economic Policy Review, 5(2), 29-51.
Özerkek, Y., \& Çelik, S. (2010). The link between government spending, consumer confidence and consumption expenditures in emerging market countries. Panoeconomicus, 57(4), 471-485.

Paiella, M. (2007). Does wealth affect consumption? Evidence for Italy. Journal of Macroeconomics, 29(1), 189-205.

Peltonen, T.A., Sousa, R.M., \& Vansteenkiste, I.S. (2012). Wealth effects in emerging market economies. International Review of Economics and Finance, 24, 155-166.

Poterba, J. (2000). Stock market wealth and consumption. Journal of Economic Perspectives, 14(2), 99-118.

Poterba, J., \& Samwick, A. (1995). Stock ownership patterns, stock market fluctuations, and consumption. Brooking Papers on Economic Activity, 1995(2), 295-372.

Singh, B. (2012). How important is the stock market wealth effect on consumption in India? Empirical Economics, 42(3), 915-927.

Slacalek, J. (2009). What drives personal consumption? The role of housing and financial wealth. The B.E. Journal of Macroeconomics, 9(1), 1-35.

Šonje, A.A., Časni, A.C., \& Vizek, M. (2014). The effect of housing and stock market wealth on consumption in emerging and developed countries. Economic Systems, 38(3), 433-450.

Starr, M., \& McCluer. (2002). The stock market wealth and consumer spending. Economic Inquiry, 40(1), 69-79.

Wang-Li, W., Hook, L. S., Said, R., \& Chin, L. (2015). Consumption and housing wealth: A Malaysian case that demonstrates a negative relationship. International Journal of Economics and Management, 9(Special Issue), 163-180.

Zhou, X., Chang, M.S., \& Gibler, K. (2016). The asymmetric wealth effects of housing market and stock market on consumption in China. Journal of the Asia Pacific Economy, 21(2), 196-216. 
HALAMAN INI SENGAJA DIKOSONGKAN 